\title{
Bioremoval of Cobalt(II) from Aqueous Solution by Three Different and Resistant Fungal Biomasses
}

\author{
Juan F. Cárdenas González, ${ }^{1}$ Adriana S. Rodríguez Pérez, ${ }^{1}$ Juan M. Vargas Morales, ${ }^{2}$ \\ Víctor M. Martínez Juárez, ${ }^{3}$ Ismael Acosta Rodríguez $\left({ }^{2},{ }^{2}\right.$ Christian Michel Cuello $\mathbb{1},{ }^{1}$ \\ Gustavo Gallegos Fonseca, ${ }^{1}$ Milka E. Escalera Chávez, ${ }^{1}$ and Alejandra Muñoz Morales ${ }^{1}$ \\ ${ }^{1}$ Unidad Académica Multidisciplinaria Zona Media, Universidad Autónoma de San Luis Potosí, \\ Carretera San Ciro de Acosta Km. 4.0, Ejido Puente del Carmen, C.P. 79617 Río Verde, San Luis Potosí, Mexico \\ ${ }^{2}$ Universidad Autónoma de San Luis Potosí, Facultad de Ciencias Químicas, Centro de Investigación y de Estudios de Posgrado, \\ Laboratorio de Micología Experimental, Av. Dr. Manuel Nava No. 6, Zona Universitaria, C.P. 78320 San Luis Potosí, \\ SLP, Mexico \\ ${ }^{3}$ Área Académica de Medicina Veterinaria y Zootecnia, Instituto de Ciencias Agropecuarias, \\ Universidad Autónoma del Estado de Hidalgo, Zona Universitaria, Rancho Universitario Km 1, \\ C.P. 43600 Tulancingo de Bravo Hidalgo, Mexico
}

Correspondence should be addressed to Ismael Acosta Rodríguez; iacosta@uaslp.mx

Received 22 May 2018; Revised 3 October 2018; Accepted 23 December 2018; Published 17 April 2019

Academic Editor: Spyros P. Perlepes

Copyright (C) 2019 Juan F. Cárdenas González et al. This is an open access article distributed under the Creative Commons Attribution License, which permits unrestricted use, distribution, and reproduction in any medium, provided the original work is properly cited.

\begin{abstract}
The biosorption of $\mathrm{Co}(\mathrm{II})$ on three fungal biomasses: Paecilomyces sp., Penicillium sp., and Aspergillus niger, was studied in this work. The fungal biomass of Paecilomyces sp. showed the best results, since it removes $93 \%$ at $24 \mathrm{~h}$ of incubation, while the biomasses of Penicillium sp. and Aspergillus niger are less efficient, since they remove the metal $77.5 \%$ and $70 \%$, respectively, in the same time of incubation, with an optimum $\mathrm{pH}$ of removal for the three analyzed biomasses of $5.0 \pm 0.2$ at $28^{\circ} \mathrm{C}$. Regarding the temperature of incubation, the most efficient biomass was that of Paecilomyces sp., since it removes $100 \%$, at $50^{\circ} \mathrm{C}$, while the biomasses of Penicillium sp. and Aspergillus niger remove $97.1 \%$ and $94.1 \%$, at the same temperature, in 24 hours of incubation. On the contrary, if the concentration of the metal is increased, the removal capacity for the three analyzed biomasses decreases; if the concentration of the bioadsorbent is increased, the removal of the metal also increases. It was observed that, after 4 and 7 days of incubation, $100 \%, 100 \%$, and $96.4 \%$ of $\mathrm{Co}(\mathrm{II})$ present in naturally contaminated water were removed, respectively.
\end{abstract}

\section{Introduction}

The discharge of heavy metals into aquatic ecosystems has become a matter of concern in recent decades. The contaminants of greatest concern include lead, chromium, mercury, zinc, arsenic, cadmium, copper, and cobalt, due to their toxic, carcinogenic, or mutagenic nature [1]. These toxic materials come mainly from mining operations, mineral refining, incinerator cannulas, metal treatment, fabrication of electronic equipment, paints, alloys, batteries, or pesticides [1]. The precursors commonly used for the elimination of metal ions from the effluents include chemical precipitation, coagulation-flocculation, ion exchange, reverse osmosis, and solvent extraction. These techniques, in addition to being very expensive, have some disadvantages, such as incomplete metal extraction, a large amount of reagents and energy, and the generation of toxic waste and other waste products that require special disposal [2].

Cobalt is a grayish-white metal with magnetic properties similar to those of iron and nickel; its main oxidation states are +2 and +3 , but in most of the available compounds of cobalt, its value is +2 . It is a relatively rare element and is produced in the earth's crust at rates ranging from $0.001-0.002 \%$, where it is found in the form of 
minerals such as cobaltite $\left(\mathrm{CoS}_{2} \bullet \mathrm{CoAs}_{2}\right)$, linnaeite $\left(\mathrm{Co}_{3} \mathrm{~S}_{4}\right)$, smaltite $\left(\mathrm{CoAs}_{2}\right)$, and erythrite $\left(3 \mathrm{CoO} \bullet \mathrm{As}_{2} \mathrm{O}_{5} \bullet 8 \mathrm{H}_{2} \mathrm{O}\right)$ [3]. Its main uses are in the production of steel with special characteristics such as hardness. In the form of oxides, it is used as a catalyst in the chemical and petroleum industry, and in the form of salts, it is used as a pigment in the ceramic industry. It is also found in the wastewater coming from the nuclear plants. This metal is responsible for many bacteria, including blue-green algae that include diatoms and chrysophytes [3].

The permissible limits of cobalt in irrigation water and wastewater from livestock are 0.05 and $1.0 \mathrm{mg} / \mathrm{L}$, respectively [4]. Acute cobalt poisoning in humans can have very serious health effects such as asthma, heart failure, and damage to the thyroid and liver [5] and can also cause mutations, and exposure to ionizing radiation is related to an increase in the risk of developing cancer [4] and decreases the growth and development in plants [6], which has increased the studies related to the removal of cobalt from wastewater. There are different physical-chemical technologies for metal removal, but due to high costs and ineffectiveness of some of them, they make bioadsorption a great alternative for the removal of trace elements [5]. In this context, biotechnology is bringing about solutions more aligned with the modern ecological demand for green processes [7]. Fungi show a capacity to absorb a great diversity of contaminants such as hydrocarbons [8], industrial wastewater [9], and metals [10] on environmentally friendly processes. Microorganisms from different genera can be promptly isolated from the environment, are fast growing, and have been showing ready adaptation to a series of challenging environmental conditions, generating many possibilities for bioremediation of cobalt, like different species of fungi: Penicillium sp. [11], Paecilomyces catenlannulatus [12], cyanobacterium Spirulina platensis [13], microalga Scenedesmus dimorphus [14], alga Hypnea valentiae [15], bacterium Pseudomonas aeruginosa SPB-1 [16], Geobacillus thermodenitrificans [17], and other biomasses-biochar form of Tectona grandis [18], chitosan grafted with maleic acid [19], and Chrysanthemum indicum [20]. Therefore, the objective of this study was to evaluate the removal of $\mathrm{Co}$ (II) in solution by the biomass of the fungi Paecilomyces sp., Penicillium sp., and Aspergillus niger, isolated in the presence of $500 \mathrm{ppm}$ of chromium(VI).

\section{Experimental}

2.1. Microorganisms and Culture Conditions. The biomasses of the fungi Paecilomyces sp., Penicillium sp., and Aspergillus niger, isolated from the air of an area close to the Faculty of Chemical Sciences of the UASLP, San Luis Potosi, S.L.P., México (the average annual temperature of $18.6^{\circ} \mathrm{C}$ and $1860 \mathrm{~m}$ above the sea level), were used in the malt agar extract. The cultures were incubated at $28^{\circ} \mathrm{C}$ for 7 days. The strains were identified based on their morphological structures such as color, diameter of the mycelia, and microscopic observation of formation of spores and macroconidia (Figure 1) [21].
2.2. Obtaining the Fungal Biomass and Cobalt(II) Solutions. The fungal biomass was obtained by inoculating a concentration of $1 \times 10^{6}$ spores $/ \mathrm{mL}$ in $1 \mathrm{~L}$ capacity Erlenmeyer flasks, which contained $600 \mathrm{ml}$ of the thioglycolate broth $(8 \mathrm{~g} / \mathrm{l})$; for its correct growth, the flasks were incubated at a temperature of $28^{\circ} \mathrm{C}$ and stirred at a constant velocity $(100 \mathrm{rpm})$. The developed fungal cells were incubated for 7 days, and then they were obtained by filtering the contents of the flasks with Whatman paper No. 1, washed twice with tri-deionized water, and then dried in an oven at $80^{\circ} \mathrm{C}$ for 12 hours. Finally, the fungal biomass was milled and stored in an amber bottle in a refrigerator until its use. For the following analysis, a series of solutions of $\mathrm{Co}$ (II) with a concentration of $200 \mathrm{mg} / \mathrm{L}$ in $100 \mathrm{~mL}$ were prepared, which were obtained from a standard solution of $1000 \mathrm{mg} / \mathrm{L}$ previously prepared with tri-deionized water; its $\mathrm{pH}$ was adjusted using nitric acid and/or $\mathrm{NaOH}$; another important factor was the amount of biomass added to each flask that was $1 \mathrm{~g} / 100 \mathrm{~mL}$ for the Co(II) solutions. Samples were taken at different times, the fungal biomass was removed by centrifugation $(3000 \mathrm{rpm} / 5 \mathrm{~min})$, and the supernatant was analyzed to determine the concentration of the metal ion.

2.3. Determination of Cobalt(II). The concentration of $\mathrm{Co}$ (II) in a water solution was determined by UV spectroscopy using a double-beam UV-visible spectrophotometer, Shimadzu UV-2101PC, by the method of methyl isobutyl ketone [22]. The Co(II) concentration of the samples was estimated using a calibration curve (concentration vs. absorbance) prepared with the standard concentration of $\mathrm{Co}(\mathrm{II})$ solutions. Calibration curves were prepared for each of the different $\mathrm{pH}$ values tested since the curves changed with $\mathrm{pH}$.

\section{Results and Discussion}

3.1. Isolation and Identification of Fungal Strains and Their Tolerance to $\mathrm{Co}(\mathrm{II})$. The fungal strains isolated were able to growth on LMM (Lee's minimal medium) supplemented with different concentrations of the metal (Figure 2). This indicates that these fungi developed the $\mathrm{Co}$ (II) tolerance and/or resistance, and they were identified by their macroscopic and microscopic characteristics [21]. The cells of the analyzed strains grew on LMM supplemented with different concentrations of $\mathrm{Co}$ (II) we obtained for the growth of three fungi at $500 \mathrm{mg} / \mathrm{L}$ : 33, 24, and $37 \mathrm{mg}$ of dry weight, for Aspergillus niger, Paecilomyces sp., and Penicillium sp., respectively. It is suggested that the fungi growing at concentrations up to $500 \mathrm{mg} / \mathrm{L}$ are tolerant and/ or resistant to the metal, which is similar to that reported by Acosta-Rodríguez et al. [10]; it is similar for Candida albicans, which grew at $300 \mathrm{mg} / \mathrm{L}$ of $\mathrm{Co}$ (II), for eight species of Penicillium isolated from Brazilian soil (tolerance between 50 and $500 \mu \mathrm{g} / \mathrm{mL}$ ); for Pichia guilliermondii isolated from acidic mine water in Peru, with a resistance to 400-600 mM of Co(II) [23]; and for the bacterium Pseudomonas aeruginosa SPB-1 (2.5 mM) [16], similar to the 

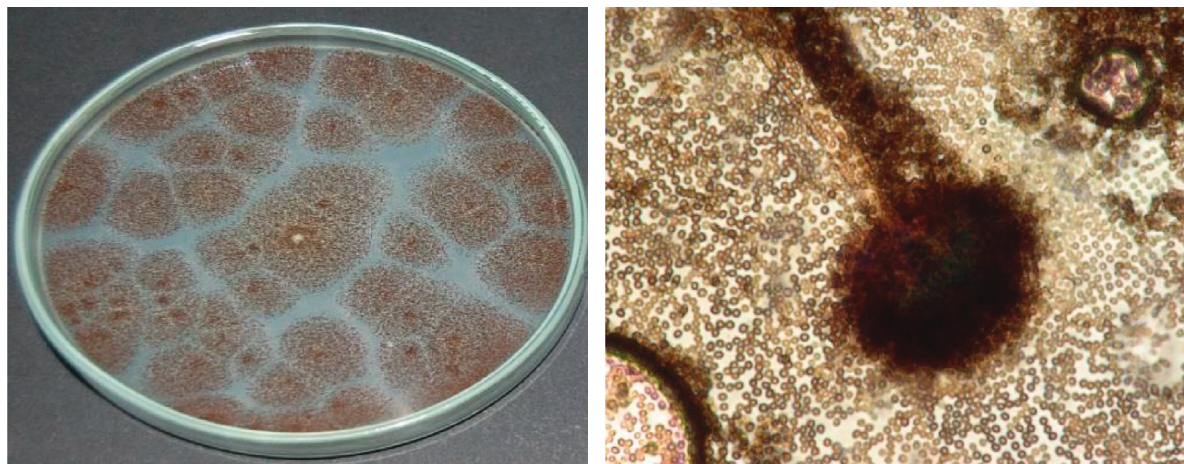

(a)
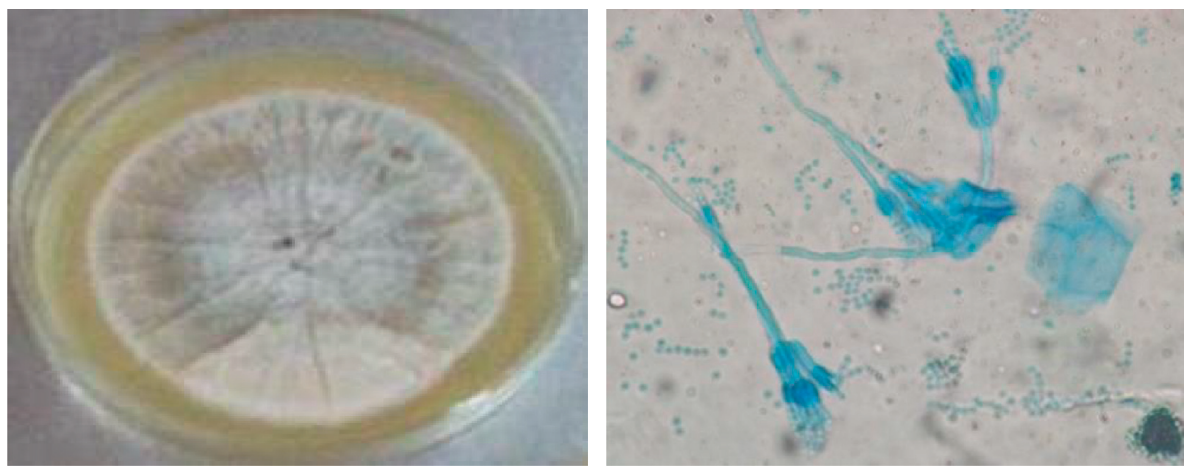

(b)
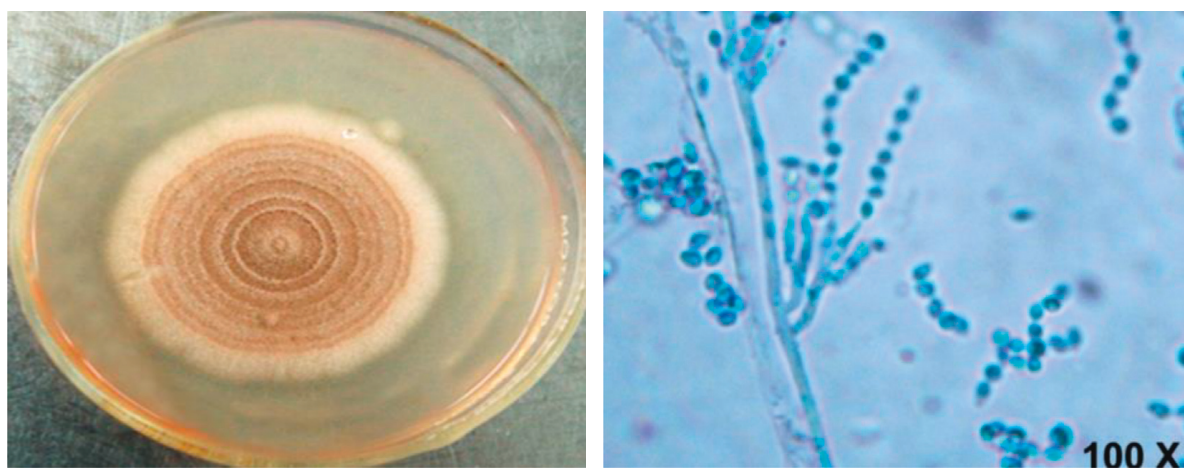

(c)

Figure 1: Fungal strains isolated from soil samples (100x). (a) Aspergillus niger; (b) Penicillium sp.; (c) Paecilomyces sp.

environmental-contaminant fungus Penicillium sp. IA-01 and which grew at a concentration of $500 \mathrm{ppm}$ of $\mathrm{Cr}(\mathrm{VI})$ in an area near the Faculty of Chemical Sciences in San Luis Potosi, México, under the same conditions [24]. The variation in the metal tolerance might be due to the unique strategies or resistance/tolerance mechanisms exhibited by the microorganisms. Resistance to $\mathrm{Co}$ (II) in Gram-negative bacteria is based on the trans-envelope efflux system driven by a resistance-nodulation-cell division (RND) transporter [25].

3.2. The Effect of Incubation Time and $p H$. Figure 3 shows the effect of contact time and $\mathrm{pH}$ on biosorption of $\mathrm{Co}$ (II) $(200 \mathrm{mg} / \mathrm{L})$ to the dried fungal biomass; it was found that the highest removal occurred in $24 \mathrm{~h}$ of incubation and at $\mathrm{pH}$ 5.0: 93\%, 77.5\%, and 70.4\%, for Paecilomyces sp., Penicillium sp., and Aspergillus niger, respectively, and these results are similar to those reported by the calcium alginate of seaweed Macrocystis pyrifera [26], by Cocos nucifera L. leaf powder [27], and by Ficus benghalensis leaf powder [28]. But they are different from those reported by Vannela and Verma [13], who reported the maximum metal biosorption by $S$. platensis biomass which was observed at $\mathrm{pH}$ 6.0, with free and immobilized biomass; by $P$. catenlannulatus, as the uptake of $\mathrm{Co}$ (II) increases with increasing $\mathrm{pH}$ from 4.5 to 7.0 and at last remains at a high level at $\mathrm{pH} 7.0$, due to formation of precipitates such as $\mathrm{Co}(\mathrm{OH})_{2}(\mathrm{~s})$ [12]; by alga $H$. valentiae, at a $\mathrm{pH}$ value of 6 [15]; and by $P$. aeruginosa SPB-1, in which the maximum adsorption of [Co(III)-EDTA] was found to be at $\mathrm{pH} 7.0$ [16]. There are slightly more advanced studies with cellular fractions of the fungus Penicillium sp. IA-01 that indicate that the optimum $\mathrm{pH}$ of reduction and that of removal of $\mathrm{Cr}(\mathrm{VI})$ is 7.0 , unlike the inert biomass in this 


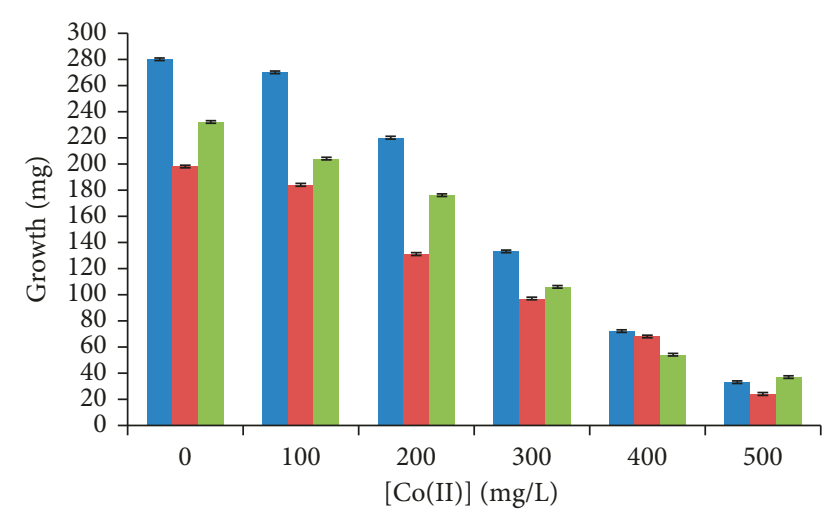

$$
\begin{aligned}
& \text { - A. niger } \\
& \text { - Paecilomyces sp. } \\
& \text { - Penicillium sp. }
\end{aligned}
$$

Figure 2: Growth in dry weight of Aspergillus niger, Paecilomyces sp., and Penicillium sp., with different concentrations of $\mathrm{Co}$ (II) $\left(1 \times 10^{6}\right.$ spores $/ \mathrm{mL}, 28^{\circ} \mathrm{C}$, seven days of incubation, $\left.100 \mathrm{rpm}\right)$.

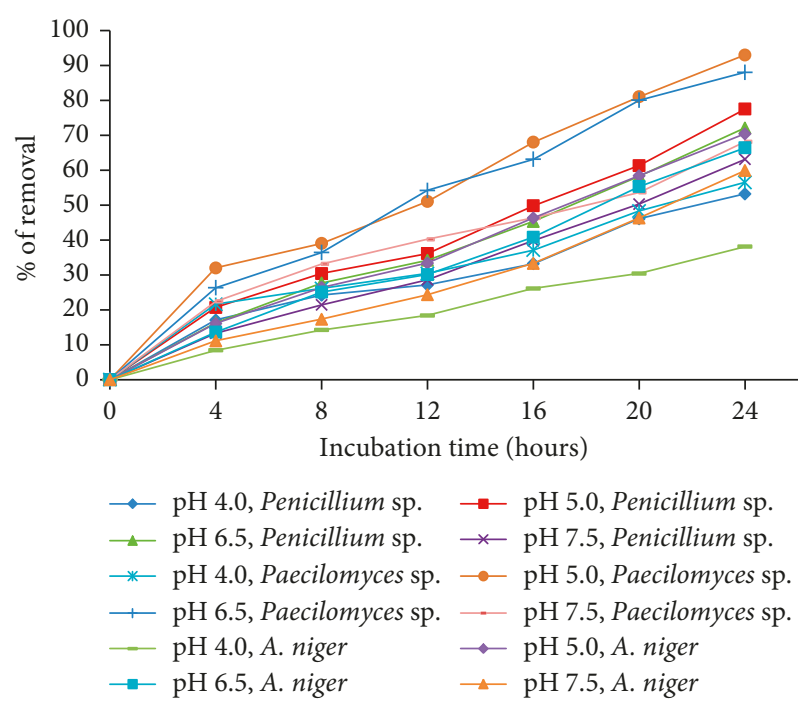

FIgURE 3: The effect of $\mathrm{pH}$ and incubation time on the removal of $\mathrm{Co}(\mathrm{II})$, by the different isolated fungi $\left(200 \mathrm{mg} / \mathrm{L} \mathrm{Co}(\mathrm{II}), 28^{\circ} \mathrm{C}\right.$, $100 \mathrm{rpm}, 5 \mathrm{~g}$ of fungal biomass).

study [24]. This phenomenon can be explained on the basis of the less competition between positively charged $\mathrm{H}^{+}$and $\mathrm{Co}^{2+}$ ions for the similar functional group. As the $\mathrm{pH}$ rises, more ligands are exposed and the number of negatively charged groups on the adsorbent matrix probably increases, improving the removal of the cationic species [15].

3.3. Effect of Temperature. Figure 4 shows the effect of varying temperatures $\left(20^{\circ} \mathrm{C}, 28^{\circ} \mathrm{C}, 40^{\circ} \mathrm{C}\right.$, and $\left.50^{\circ} \mathrm{C}\right)$, and the maximal adsorption capacity was found at $50 \pm 1^{\circ} \mathrm{C}$ : $100 \%$, 97.1\%, and $94.1 \%$, for Paecilomyces sp., Penicillium sp., and A. niger, respectively, at 24 hours, and these results are similar to those reported for $P$. catenlannulatus, as the uptake of $\mathrm{Co}(\mathrm{II})$ increases with increasing temperature from 20 to $40^{\circ} \mathrm{C}$ [12], P. aeruginosa SPB-1 [16], Cocos nucifera L. leaf powder [27], and F. benghalensis leaf powder [28] and

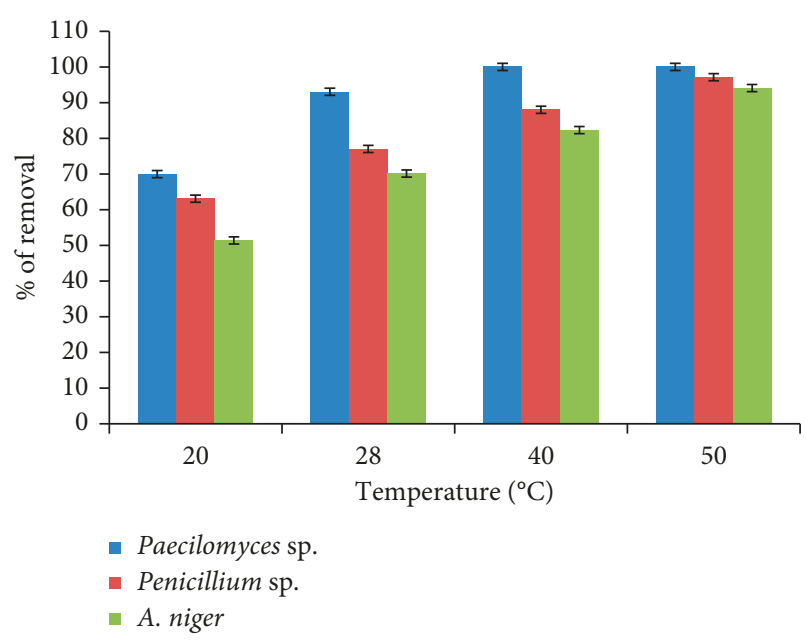

FIgURE 4: The effect of the temperature on removal of $\mathrm{Co}(\mathrm{II})$, by the different isolated fungi $(200 \mathrm{mg} / \mathrm{L} \mathrm{Co}(\mathrm{II}), 100 \mathrm{rpm}, \mathrm{pH} 5.0,24 \mathrm{~h}, 5 \mathrm{~g}$ of fungal biomass).

are different from those reported for alga H. valentiae [15], in which it can be seen that the maximum monolayer capacity of the adsorbent decreases from 47.44 to $46.03 \mathrm{mg} / \mathrm{L}$ by increasing the temperature from $25^{\circ} \mathrm{C}$ to $45^{\circ} \mathrm{C}$. On the contrary, enhancement of the adsorption capacity of the fungal biomasses at higher temperatures may be attributed to the activation of the adsorbing surface and the accelerated diffusivity of the metal with the increasing temperature and increase in the mobility of metal ions [12].

3.4. Effect of Initial Co(II) Concentration. Biosorption capacities of the fungal biomasses for the $\mathrm{Co}(\mathrm{II})$ were studied as a function of the initial metal concentration between 50 and $500 \mathrm{mg} / \mathrm{L}$ (Figure 5), and the percentage of adsorption decreased, when $\mathrm{Co}(\mathrm{II})$ concentration increased from $300 \mathrm{mg} / \mathrm{L}$ for the three fungal biomasses. It has been observed that, in some genera of algae, calcium alginates of algae, and rice straw, the removal is diminished by increasing the initial concentration of $\mathrm{Co}(\mathrm{II})[15,26,29]$, but it is different from $S$. platensis, since increasing the initial concentration of $\mathrm{Co}$ (II) increases the removal of it, attaining a maximum value of $181 \mathrm{mg} \mathrm{Co}(\mathrm{II}) / \mathrm{g}$ at $600 \mathrm{mg} / \mathrm{L}$ concentration of $\mathrm{Co}$ (II) [13], for leaves of T. grandis (teak) tree collected from the farmlands in Vellore District, India [18]. Vilvanathan and Shanthakumar suggest that the percentage of the metal captured is directly proportional to the concentration of the metal and that it is due to the difference between forces given by the adsorption process; in $C$. indicum, it can be observed that the amount of metal ion uptake also increased from 11.7 to $15.2 \mathrm{mg} / \mathrm{g}$ with increasing $\mathrm{Co}$ (II) ion concentration from 25 to $75 \mathrm{mg} / \mathrm{L}$ [20]. This may be due to the increased number of competitions for the functional groups of the surface of the biomass ions [30].

3.5. Effect of Initial Biomass Concentration. The effect of amount of biomass on the removal capacity of $\mathrm{Co}(\mathrm{II})$ is depicted in Figure 6. If the amount of biomass is increased, 


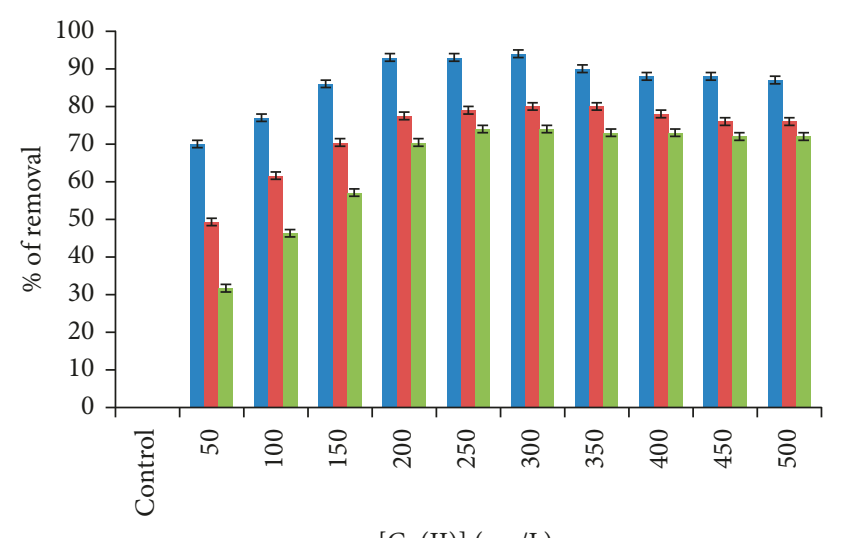

$[\mathrm{Co}(\mathrm{II})](\mathrm{mg} / \mathrm{L})$

$$
\begin{aligned}
& \text { - Paecilomyces sp. } \\
& \text { - Penicillium sp. } \\
& \text { - A. niger }
\end{aligned}
$$

FIgURE 5: The effect of the concentration of $\mathrm{Co}(\mathrm{II})$ in solution on the removal of $\mathrm{Co}$ (II) by the different isolated fungi $\left(100 \mathrm{rpm}, 28^{\circ} \mathrm{C}\right.$, $\mathrm{pH} 5.0,5 \mathrm{~g}$ of fungal biomass).

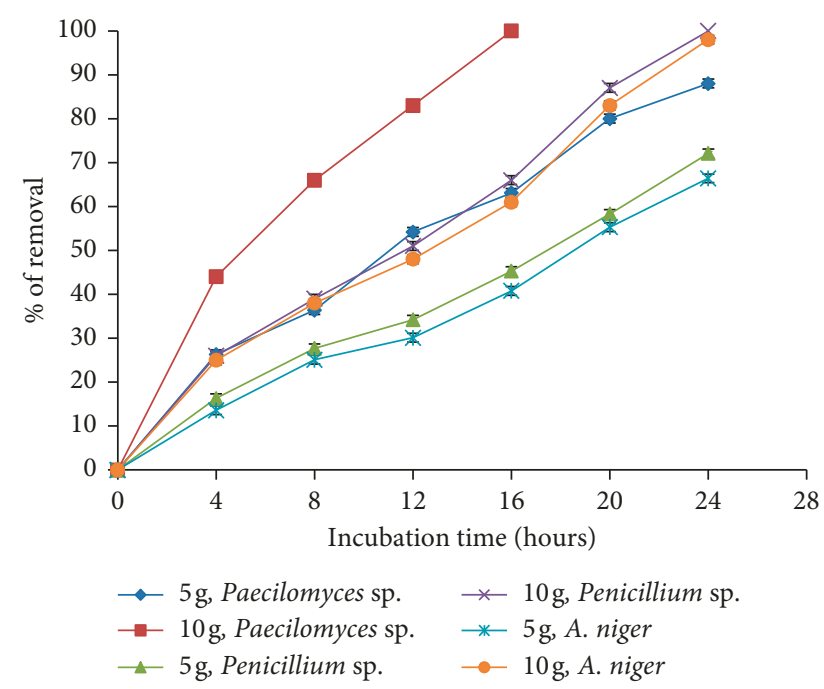

FIgURE 6: The effect of fungal biomass concentration on the removal of $\mathrm{Co}(\mathrm{II})\left(500 \mathrm{mg} / \mathrm{L}, 100 \mathrm{rpm}, 28^{\circ} \mathrm{C}, \mathrm{pH} \mathrm{5.0,} 24\right.$ hours).

the removal of the metal in the solution is also increased; when $10 \mathrm{~g}$ of the fungal biomass of Paecilomyces sp. is used instead of $5 \mathrm{~g}$, it can be seen that $100 \%$ of the metal is removed in 16 hours; other filamentous fungi such as Penicillium sp. and Aspergillus niger showed excellent metal removal capacity at 24 hours with $100 \%$ and $98 \%$ removal, respectively; many authors agree with the fact that, by increasing the amount of biomass, the metal removal capacity increases because the amount of the added biosorbent determines the number of binding sites available for metal biosorption [31]. Similar results have been reported for $P$. aeruginosa SPB-1 [16], for the seaweed alga $M$. pyrifera [26], and for the adsorptive removal of $\mathrm{Co}(\mathrm{II})$ from aqueous solutions using C. nucifera L. [27], with nanocellulose/ nanobentonite composite anchored with multicarboxyl functional group experiments, with various amounts of adsorbent ranging between 0.05 and $5.0 \mathrm{~g} / \mathrm{L}$ [32].
3.6. Removal of Co(II) in Industrial Wastes with Fungal Biomasses. To analyze the possible application of the three fungal biomasses at the industrial level and their ability to remove $\mathrm{Co}$ (II) from sediments and real effluents, an aqueous solution assay was used where $5 \mathrm{~g}$ of the fungal biomass was used, with $100 \mathrm{~mL}$ of wastewater which contains $100 \mathrm{mg}$ of $\mathrm{Co}(\mathrm{II})$, at $28^{\circ} \mathrm{C}$ and stirred at $100 \mathrm{rpm}$. The samples were taken from Tanque Tenorio (located at east of the city of San Luis Potosi, México) which was used in the seventies as a dump of industrial waste and years later also served as a wastewater dump [33]; later, these waters were used for the irrigation of crops in agriculture and as drinking troughs for animals [34]; sources of pollution were identified that generate $\mathrm{Hg}, \mathrm{Ba}, \mathrm{Sr}, \mathrm{Cd}, \mathrm{Pb}, \mathrm{Ag}, \mathrm{Rb}, \mathrm{Co}, \mathrm{Cu}, \mathrm{Fe}$, and $\mathrm{As}$, and some exceed the permissible limit for human consumption [35]. In this study, we were able to observe that, after four days of incubation, $100 \%$ of $\mathrm{Co}$ (II) present in naturally contaminated water and soil was removed by the filamentous fungus Paecilomyces sp. and $96.4 \%$ by Penicillium sp. and $A$. niger, respectively, at seven days (Figure 7). The ability to remove by biomass is equal to or greater than that by other biomasses that have been studied, for different heavy metals, like $C$. albicans biomass to remove chromium(VI) from sediments and effluents, in which 74 and $69 \%$ of metal present in the contaminated water and soil were removed [10], and Botryococcus braunii biomass to remove $\mathrm{As}(\mathrm{III})$ and $\mathrm{As}(\mathrm{V})$ ions from the $50 \mathrm{mg} / \mathrm{L}$ synthetic wastewater, in which $85.22 \%$ and $88.15 \%$ of maximum removal efficiency were achieved [36]. Also, C. tropicalis was observed to remove $40 \% \mathrm{Cd}$ (II) from the wastewater after 6 days and was also able to remove $78 \%$ from the wastewater after 12 days [37]; different species of the genus Aspergillus have the capacity to remove approximately between 20 and $50 \%$ of $100 \mathrm{mg} / \mathrm{L}$ of $\mathrm{Hg}$ (II) using $1 \mathrm{~g}$ of biomass, with a temperature of $30^{\circ} \mathrm{C}$ and a $\mathrm{pH}$ of 5.5 ; these data are lower than those reported in this research because mercury is more toxic and causes the inhibition of cellular glucose uptake and then cellular respiration, and therefore, there is no growth of microorganisms [38]. Saccharomyces cerevisiae and Torulaspora delbrueckii decrease in 98.1, 83.0, 60.7, 60.5, and $54.2 \%$ for turbidity, sulfates, BOD, phosphates, and COD, respectively, of the tannery effluent [39], and for S. cerevisiae, "wild-type" (WT) parental strain BY4741 is very efficient in removing $\mathrm{Mn}(\mathrm{II}), \mathrm{Cu}(\mathrm{II})$, and $\mathrm{Co}(\mathrm{II})$ from synthetic effluents containing $1-2 \mathrm{mM}$ cations [40].

\section{Conclusion}

The contamination by heavy metals is a serious health and ecological problem. The removal of Co(II) by three different fungal biomasses was investigated. The resistant isolated filamentous fungi have high $\mathrm{Co}$ (II) elimination capacity. For the determination of the removal capacity of $\mathrm{Co}$ (II), different aspects or operating conditions were analyzed such as incubation time, $\mathrm{pH}$, initial metal ion concentration, and fungal biomass. With the data obtained, it is clearly observed that the best conditions for the elimination of $\mathrm{Co}$ (II) were a temperature of $50^{\circ} \mathrm{C}$, a $\mathrm{pH}$ of 5.0 , and an incubation time of 24 hours, and it was observed that, by increasing the amount 


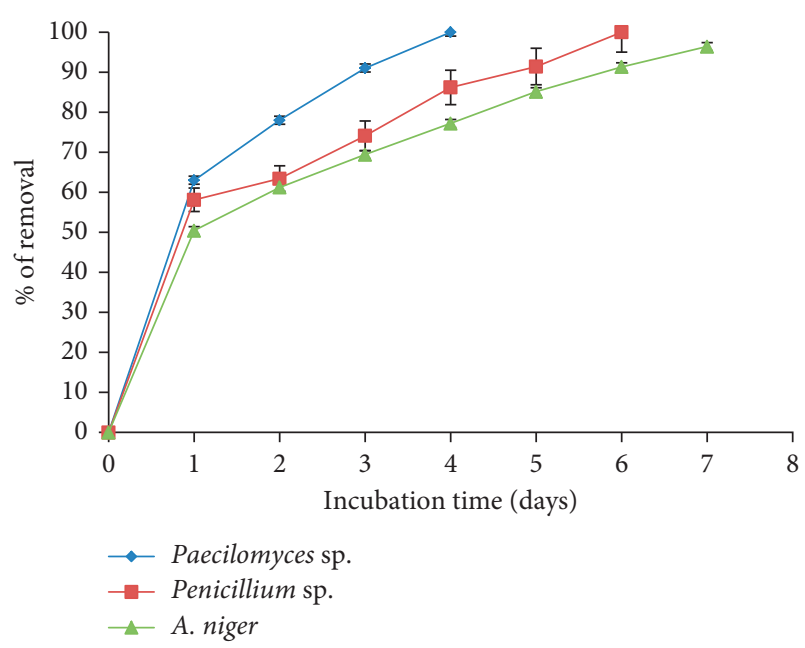

Figure 7: Removal of $100 \mathrm{mg} / \mathrm{L}$ of $\mathrm{Co}(\mathrm{II})$ (adjusted) from wastewater $\left(100 \mathrm{rpm}, 28^{\circ} \mathrm{C}, \mathrm{pH} 5.0,5 \mathrm{~g}\right.$ of fungal biomass).

of biomass to a maximum of $10 \mathrm{~g}$ in this study with the three resistant fungi, the metal removal capacity increased. In the case of the removal of $\mathrm{Co}(\mathrm{II})$ from natural contaminated waste such as water and soil, we could observe that the metal was removed $100 \%$ at a maximum time of four days with the fungus Paecilomyces sp. The easy determination of this type of biomaterial is of great ecological and economic importance for the sustainability of the ecosystems; filamentous fungi isolated Paecilomyces sp., Penicillium sp., and Aspergillus niger are very promising biomaterials for the removal of cobalt(II) analyzed.

\section{Data Availability}

The images and graphics data used to support the findings of this study are included within the article; this information can also be consulted through direct contact with the authors via the following email IDs: Dr. Ismael Acosta (iacosta@ uaslp.mx) and Dr. Juan Cárdenas (juan.cardenas@ uaslp.mx).

\section{Conflicts of Interest}

The authors declare that there are no conflicts of interest regarding the publication of this paper.

\section{Authors' Contributions}

Dr. Juan Cárdenas, Dra. Adriana Rodríguez, Dr. Ismael Acosta, Dr. Juan Manuel Vargas, Dr. Víctor Martínez, Dr. Christian Michel, Dr. Gustavo Gallegos, Dra. Milka Escalera, and Dra. Alejandra Muñoz were involved in conceptualization. Dr. Juan Cárdenas, Dra. Adriana Rodríguez, Dr. Ismael Acosta, Dr. Juan Manuel Vargas, Dr. Víctor Martínez, Dr. Christian Michel, Dr. Gustavo Gallegos, Dra. Milka Escalera, and Dra. Alejandra Muñoz were involved in methodology. Dr. Juan Cárdenas, Dra. Adriana Rodríguez, and Dr. Ismael Acosta were responsible for project administration. Dr. Juan Círdenas, Dra. Adriana Rodríguez, Dr. Ismael Acosta, Dr. Juan Manuel Vargas, Dr. Víctor
Martínez, Dr. Christian Michel, Dr. Gustavo Gallegos, Dra. Milka Escalera, and Dra. Alejandra Muñoz were responsible for resources. Dr. Juan Cárdenas, Dra. Adriana Rodríguez, and Dr. Ismael Acosta were responsible for supervision. Dr. Juan Manuel Vargas, Dr. Víctor Martínez, Dr. Christian Michel, Dr. Gustavo Gallegos, Dra. Milka Escalera, and Dra. Alejandra Muñoz were involved in validation. Dr. Juan Cárdenas, Dra. Adriana Rodríguez, Dr. Ismael Acosta, Dr. Juan Manuel Vargas, Dr. Víctor Martínez, Dr. Christian Michel, Dr. Gustavo Gallegos, Dra. Milka Escalera, and Dra. Alejandra Muñoz were involved in visualization (our research group has together every one that has to publish some work to make it ready in its entirety for the publisher). Dr. Juan Cárdenas, Dra. Adriana Rodríguez, and Dr. Ismael Acosta were involved in writing original draft. Dr. Juan Cárdenas, Dra. Adriana Rodríguez, Dr. Ismael Acosta, Dr. Juan Manuel Vargas, Dr. Víctor Martínez, Dr. Christian Michel, Dr. Gustavo Gallegos, Dra. Milka Escalera, and Dra. Alejandra Muñoz were involved in writing, review, and editing.

\section{Acknowledgments}

This work was financially supported by Programa para el Desarrollo Profesional Docente (PRODEP) realized in the Universidad Autónoma de San Luis Potosi with number assignment 511-6/17-7930.

\section{References}

[1] S. H. Abbas, I. M. Ismail, T. M. Mostafa, and A. H. Sulaymon, "Biosorption of heavy metals: a review," Journal of Chemical Science and Technology, vol. 3, no. 4, pp. 74-102, 2014.

[2] W. Bahafid, N. T. Joutey, M. Asri, H. Sayel, N. Tirry, and N. El Ghachtouli, "Yeast biomass: an alternative for bioremediation of heavy metals," in Yeast-Industrial Applications, A. Morata, Ed., Intehopen, Croatia, 1st edition, 2017.

[3] Cobalto. Departamento De Salud Y Servicios Humanos De Los Ee.Uu, Servicio de Salud Pública Agencia para Sustancias Tóxicas y el Registro de Enfermedades, Department of Health and Human Services, Atlanta, GA, USA, 2004.

[4] S. Rengaraj and S.-H. Moon, "Kinetics of adsorption of Co(II) removal from water and wastewater by ion Exchange resins," Water Research, vol. 36, no. 7, pp. 1783-1793, 2002.

[5] A. Bhatnagar, A. K. Minocha, and M. Sillanpää, "Adsorptive removal of cobalt from aqueous solution by utilizing lemon peel as biosorbent," Biochemical Engineering Journal, vol. 48, no. 2, pp. 181-186, 2010.

[6] S. Leenu and D. Sheela, "Impact of Co and $\mathrm{Cu}$ (heavy metals) on Eichhornia crassipes (mart.) solms, with special reference to bioaccumulation and phytoremediation," Asian Journal of Science and Technology, vol. 7, no. 5, pp. 2996-2998, 2016.

[7] A. Rehman and M. Sohail Anjum, "Cadmium uptake by yeast, Candida tropicalis, isolated from industrial effluents and its potential use in wastewater clean-up operations," Water, Air, and Soil Pollution, vol. 205, no. 1-4, pp. 149-159, 2009.

[8] M. G. Moctezuma -Zarate, J. F. Cárdenas-González, A. Rodríguez-Pérez et al., "Isolation and identification of bacteria and fungi resistant to crude oil," Journal of Multidisciplinary Engineering Science and Technology, vol. 3, no. 7, pp. 5273-5278, 2016. 
[9] N. U. Asamudo, A. S. Daba, and O. U. Ezeronye, "Bioremediation of textile effluent using Phanerochaete chrysosporium," African Journal of Biotechnology, vol. 4, no. 13, pp. 1548-1553, 2005.

[10] I. Acosta-Rodríguez, J. F. Cárdenas-González, V. M. MartínezJuárez, A. Rodríguez-Pérez, M. G. Moctezuma-Zarate, and N. C. Pacheco-Castillo, "Biosorption of heavy metals by Candida albicans," in Advances in Bioremediation and Phytoremediation, N. Shiomi, Ed., Intechopen, Croatia, 1st edition, 2018.

[11] L. R. Martins, F. H. Lyra, M. M. H. Rugani, and J. A. Takahashi, "Bioremediation of metallic ions by eight Penicillium species," Journal of Environmental Engineering, vol. 142, no. 9, pp. C4015007-C4015007-8, 2016.

[12] F. Li, Z. Gao, X. Li, and L. Fang, "The effect of environmental factors on the uptake of ${ }^{60} \mathrm{Co}$ by Paecilomyces catenlannulatus," Journal of Radioanalytical and Nuclear Chemistry, vol. 299, no. 3, pp. 1281-1286, 2013.

[13] R. Vannela and S. K. Verma, " $\mathrm{Co}^{2+}, \mathrm{Cu}^{2+}$, and $\mathrm{Zn}^{2+}$ accumulation by Cyanobacterium Spirulina platensis," Biotechnology Progress, vol. 22, no. 5, pp. 1282-1293, 2006.

[14] N. Bordoloi, R. Goswami, M. Kumar, and R. Kataki, "Biosorption of $\mathrm{Co}$ (II) from aqueous solution using algal biochar: kinetics and isotherm studies," Bioresource Technology, vol. 244, pp. 1465-1469, 2017.

[15] L. Vafajoo, R. Cheraghi, R. Dabbagh, and G. McKay, "Removal of cobalt (II) ions from aqueous solutions utilizing the pre-treated 2-Hypnea Valentiae algae: equilibrium, thermodynamic, and dynamic studies," Chemical Engineering Journal, vol. 331, pp. 39-47, 2018.

[16] A. Paraneeiswaran, S. K. Shukla, T. Subba Rao, and K. Prashanth, "Removal of toxic Co-EDTA complex by a halophilic solar-salt-pan isolate Pseudomonas aeruginosa SPB-1," Chemosphere, vol. 95, pp. 503-510, 2014.

[17] S. K. Chatterjee, I. Bhattacharjee, and G. Chandra, "Biosorption of heavy metals from industrial waste water by Geobacillus thermodenitrificans," Journal of Hazardous Materials, vol. 175, no. 1-3, pp. 117-125, 2010.

[18] S. Vilvanathan and S. Shanthakumar, "Column adsorption studies on nickel and cobalt removal from aqueous solution using native and biochar form of Tectona grandis," Environmental Progress \& Sustainable Energy, vol. 36, no. 4, pp. 1030-1038, 2017.

[19] S. Zhuang, Y. Yin, and J. Wang, "Removal of cobalt ions from aqueous solution using chitosan grafted with maleic acid by gamma radiation," Nuclear Engineering and Technology, vol. 50, no. 1, pp. 211-215, 2018.

[20] S. Vilvanathan and S. Shanthakumar, "Modeling of fixed-bed column studies for removal of cobalt ions from aqueous solution using Chrysanthemum indicum," Research on Chemical Intermediates, vol. 43, no. 1, pp. 229-243, 2016.

[21] M. P. Kirk, F. P. Cannon, C. J. David, and A. J. Stalpers, Dictionary of the Fungi, CABI Publishing, UK, 2001.

[22] G. Charlot, Colorimetric Determination of Elements, Elsevier Publishing Company-Amsterdam-London-New York, New York, NY, USA, 12th edition, 1964.

[23] J. Orbegozo, M. Abanto, R. García, and P. Ramírez, "Molecular identification of Pichia guillermondii isolated from mine water acidic of Peru and its resistance to heavy metals," Revista Peruana de Biología, vol. 15, no. 1, pp. 91-96, 2008.

[24] I. Acosta-Rodríguez, D. L. Arévalo-Rangel, J. F. CárdenasGonzález, M. G. Moctezuma-Zarate, and V. M. MartínezJuárez, "Hexavalent chromium (VI) removal by Penicillium sp. IA-01," in Advances in Bioremediation of Wastewater and Polluted Soil, N. Shiomi, Ed., Intechopen, Croatia, 2015.

[25] D. H. Nies, "Microbial heavy-metal resistance," Applied Microbiology and Biotechnology, vol. 51, no. 6, pp. 730-750, 1999.

[26] M. Rabanal Atalaya, "Estudio de la biosorción de Co(II) por el alga marina Macrocistis piryfera, Químico," Tesis Profesional, Universidad Nacional Mayor de San Marcos, Lima, Perú, 2006.

[27] D. Hymavathi and G. Prabhakar, "Optimization, equilibrium, and kinetic studies of adsorptive removal of cobalt(II) from aqueous solutions using Cocos nucifera L," Chemical Engineering Communications, vol. 204, no. 9, pp. 1094-1104, 2017.

[28] D. Hymavathi and G. Prabhakar, "Studies on the removal of Cobalt(II) from aqueous solutions by adsorption with Ficus benghalensis leaf powder through response surface methodology," Chemical Engineering Communications, vol. 204, no. 12, pp. 1401-1411, 2017.

[29] A. A. Swelam, M. B. Awad, A. M. A. Salem, and A. S. El-Feky, "Biosorption of cobalt(II) ions from aqueous solution using rice straw and its modification," Journal of Scientific Engineering Research, vol. 4, no. 1, pp. 121-129, 2017.

[30] C. Tejada-Tovar, Á. Villabona-Ortiz, and L. Garcés-Jaraba, "Adsorción de metales pesados en aguas residuales usando materiales de origen biológico," TecnoLógicas, vol. 18, no. 34, pp. 109-123, 2015.

[31] S. Chowdhury and P. Saha, "Sea shell powder as a new adsorbent to remove Basic Green 4 (Malachite Green) from aqueous solutions: equilibrium, kinetic and thermodynamic studies," Chemical Engineering Journal, vol. 164, no. 1, pp. 168-177, 2010.

[32] T. S. Anirudhan, J. R. Deepa, and J. Christa, "Nanocellulose/ nanobentonite composite anchored with multi-carboxyl functional groups as an adsorbent for the effective removal of Cobalt(II) from nuclear industry wastewater samples," Journal of Colloid and Interface Science, vol. 467, pp. 307-320, 2016.

[33] B. López Álvarez, "Cambios de uso de suelo y su impacto en el sistema acuífero del valle de San Luís Potosí, aplicando modelación numérica," Tesis Doctoral En Ciencias Ambientales, Instituto Potosino de Ciencia y Tecnología, San Luis Potosí, SLP, México, 2012.

[34] Comité Técnico del Agua Subterránea (COTAS), “Estudio técnico respecto a las condiciones geohidrológicas y sociales del acuífero 2411 "San Luis Potosí" en el Estado de San Luis Potosí: San Luis Potosí," reporte, 74, Comité Técnico de Agua Subterránea del Acuífero del Valle de San Luis Potosí, Comité Técnico del Agua Subterránea (COTAS), Rio Verde, San Luis Potosi, 2005.

[35] Norma Oficial Mexicana Nom-127-SSA1-1994, "Salud ambiental, agua para uso Y consumo humano-limites permisibles de calidad Y tratamientos a que debe someterse el agua para su potabilizacion," Estados Unidos Mexicanos, Secretaría de Salud, Norma Oficial Mexicana Nom-127-SSA11994, Mexico, 1994.

[36] M. S. Podder and C. B. Majumder, "The use of artificial neural network for modelling of phycoremediation of toxic elements As(III) and As(V) from wastewater using Botryococcus braunii," Spectrochimica Acta Part A: Molecular and Biomolecular Spectroscopy, vol. 155, pp. 130-145, 2016.

[37] A. Rehman and M. S. Anjum, "Multiple metal tolerance and biosorption of cadmium by Candida tropicalis isolated from industrial effluents: glutathione as detoxifying agent," 
Environmental Monitoring and Assessment, vol. 174, no. 1-4, pp. 585-595, 2010.

[38] V. M. Martínez-Juárez, J. F. Cárdenas-González, M. E. TorreBouscoulet, and I. Acosta-Rodríguez, "Biosorption of mercury (II) from aqueous solutions onto fungal biomass," Bioinorganic Chemistry and Applications, vol. 2012, Article ID 156190, 5 pages, 2012.

[39] S. I. R. Okoduwa, B. Igiri, C. Blessing Udeh, C. Edenta, and B. Gauje, "Tannery effluent treatment by yeast species isolates from watermelon," Toxics, vol. 5, no. 1, p. 6, 2017.

[40] L. Ruta, C. Paraschivescu, M. Matache, S. Avramescu, and I. C. Farcasanu, "Removing heavy metals from synthetic effluents using "kamikaze" Saccharomyces cerevisiae cells," Applied Microbiology and Biotechnology, vol. 85, no. 3, pp. 763-771, 2009. 

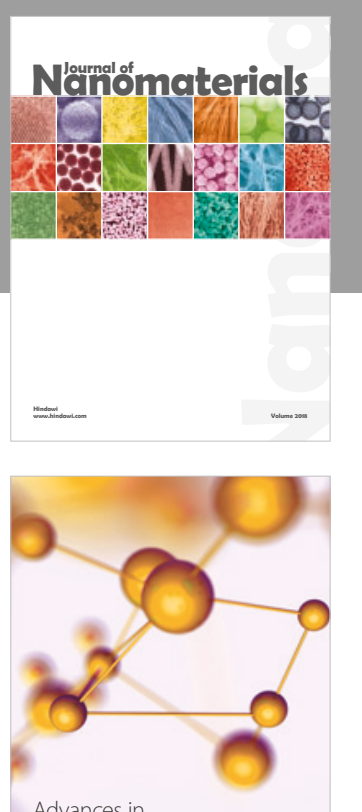

Physical Chemistry
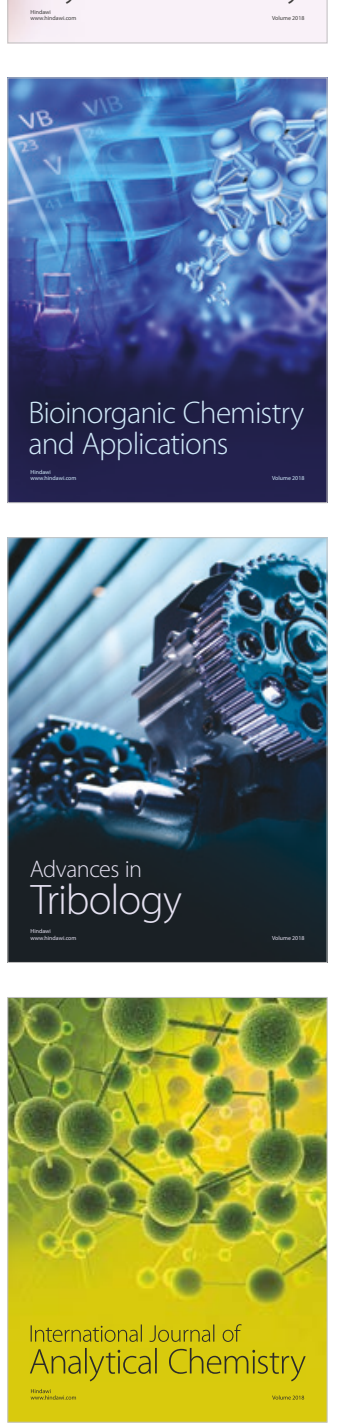

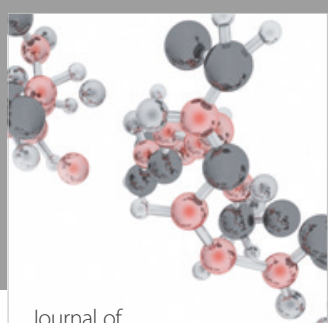

Analytical Methods

in Chemistry

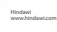

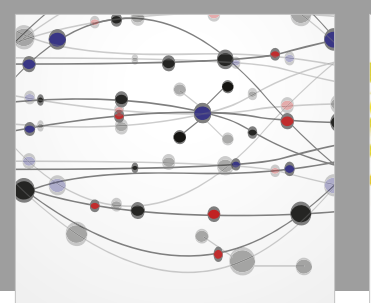

The Scientific World Journal

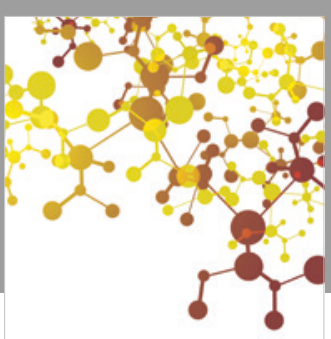

Journal of

Applied Chemistry
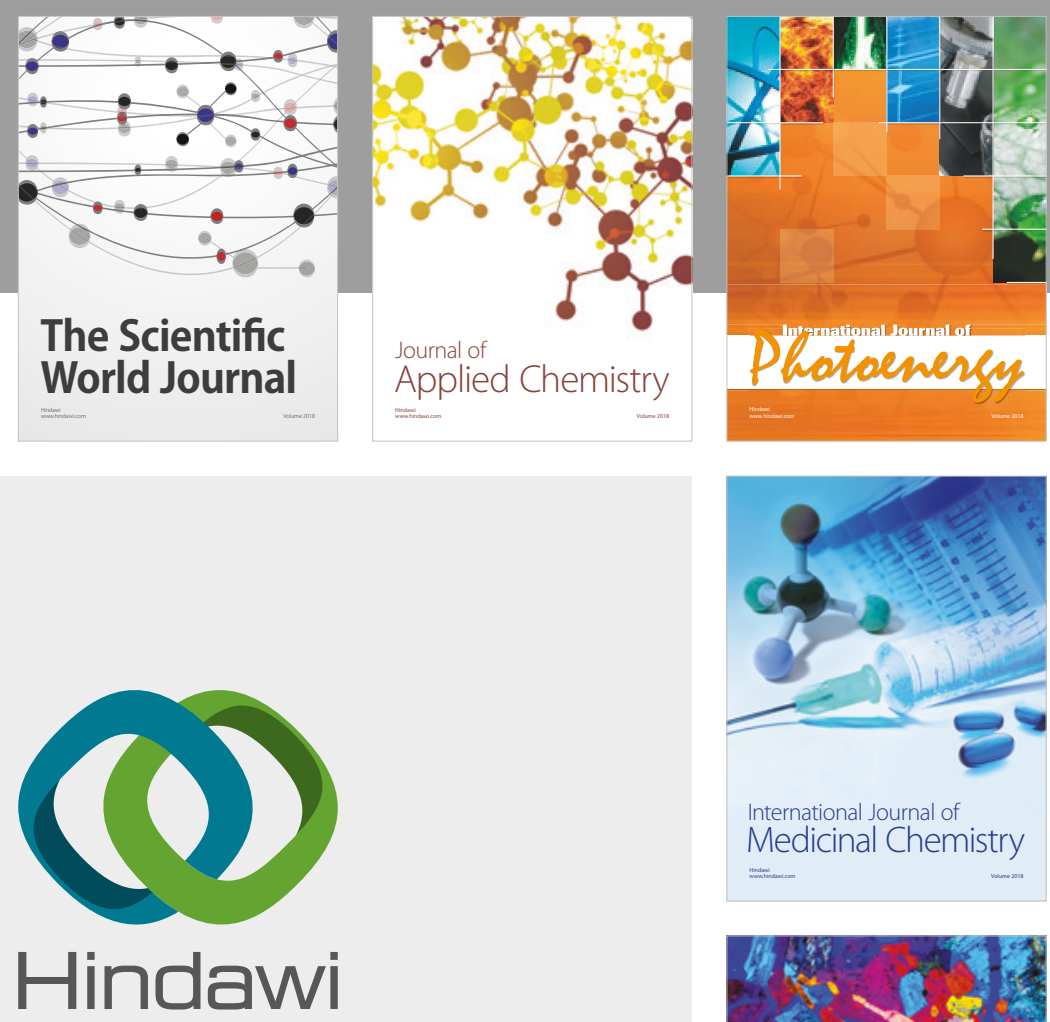

Submit your manuscripts at

www.hindawi.com
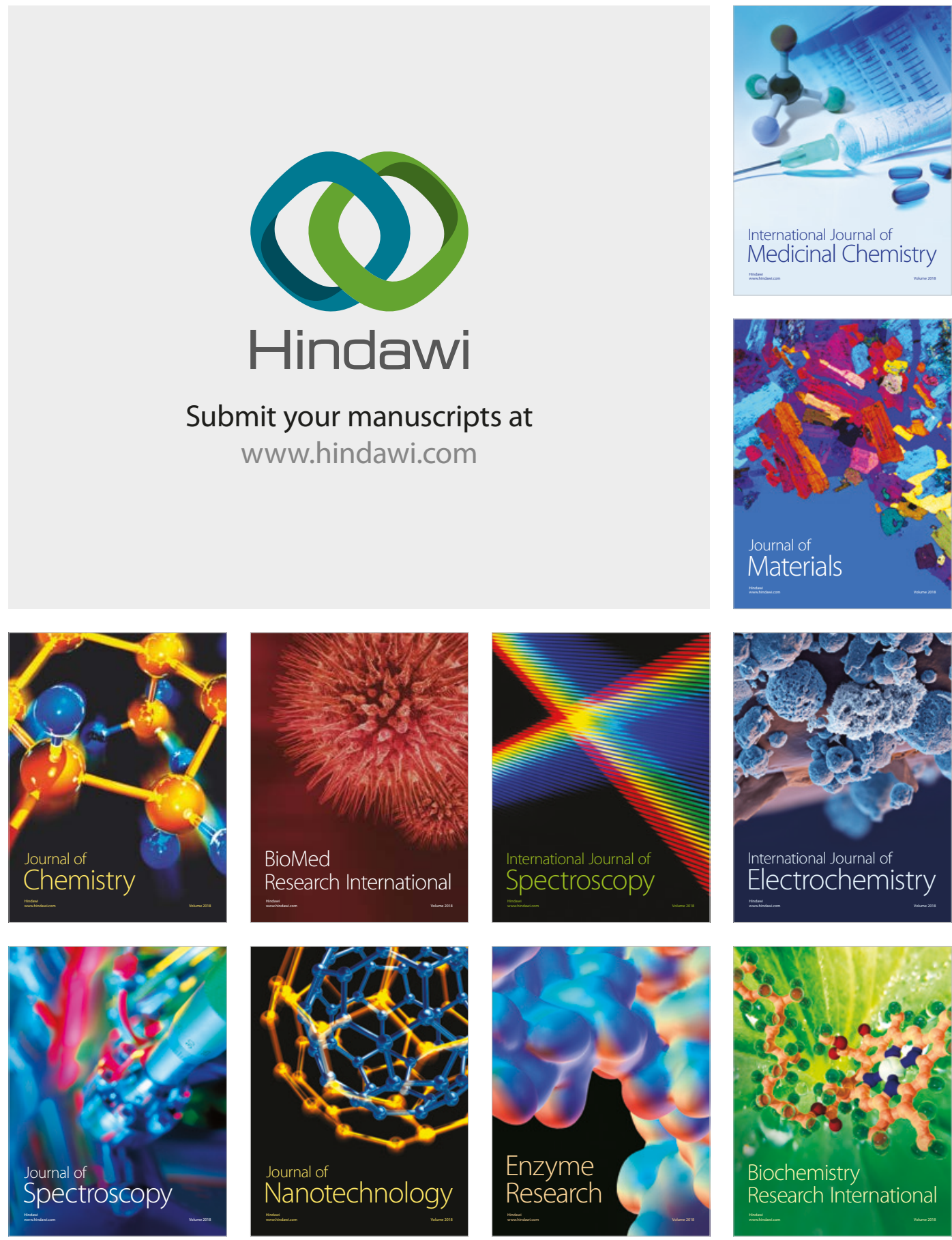
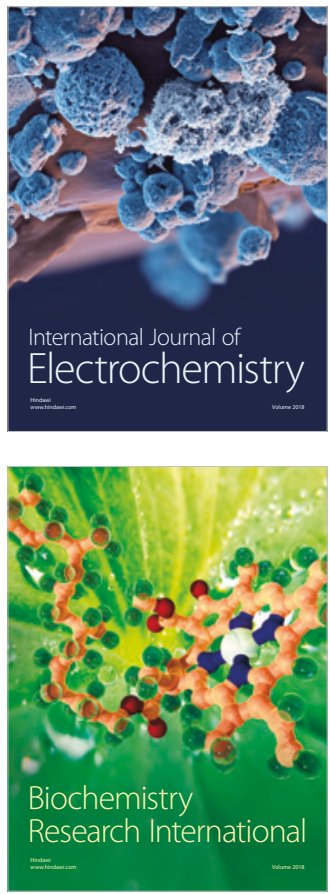